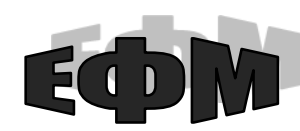

http://efm.vsau.org/

\title{
L51, M38
}

УАК 338.2. 351

\section{STATE REGULATION IN THE FIELD OF \\ TELECOMMUNICATIONS: CONCEPT AND MECHANISMS}

I. VORONENKO, Candidate of Economic Sciences, Senior Researcher, Doctoral Student of the Department of Economic Cybernetics, National University of Life and Environmental Sciences of Ukraine (Kyiv)

The article deals with and generalizes scientific approaches to the definition of the essence of state regulation. It has been established that along with the notion of state regulation of widespread use, the concepts of "public administration" and "governance" became known. Through the comparative analysis, the content of those notions are revealed. During the study, the lack of a common understanding and commonly accepted interpretation of the concept of state regulation is found. The main provisions regarding the key principles of the state regulatory policy of Ukraine are presented.

It is noted that the regulation of natural monopolies in Ukraine is carried out by the National Commissions, which are central executive bodies with a special status, which are formed and liquidated by the President of Ukraine. Some features of functioning of the regulatory authorities of the sphere of telecommunications on the example of the countries of the European Community and Ukraine as such are investigated.

It is concluded that the total number of authorities that should be regulated by the regulatory body in the field of telecommunications, which is responsible for the adoption of the budget regulator varies according to EU countries. However, the main source of financing for telecoms regulatory authorities in most EU countries is revenue from their own activities.

Special attention was paid to the study of the functions of regulatory bodies in the field of telecommunications. It is concluded that an important part of the regulatory bodies' activities is the provision of universal services as an important social component of the market.

Key words: public administration, governance, state regulation, national commission, regulatory authorities, field of telecommunications.

Tabl.: 1. Fig.: 3. Ref.: 25.

\section{ДЕРЖАВНЕ РЕГУЛЮВАННЯ У СФЕРІ ТЕЛЕКОМУНІКАЦЙ: КОНЦЕПТ} ТА МЕХАНІЗМИ

ВОРОНЕНКО Ірина Вікторівна, кандидат економічних наук, стариий науковий співробітник, докторант кафедри економічної кібернетики, Національний університет біоресурсів і природокористування Украйни (м. Kuїв)

I VORONENKO, 2019 


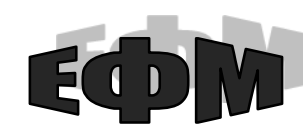

http://efm.vsau.org/

У статті розглянуто та узагальнено наукові підходи до визначення сутності державного регулювання. Встановлено, щз поруч з поняттям державного регулювання широкого вживання набули поняття "публічне управління" та “держсавне управління”. Шляхом порівняльного аналізу розкрито зміст понять та їх взаємозв'язок. У ході дослідження виявлено відсутність єдиного розуміння та загальноприйнятого трактування поняття державного регулювання.

Зазначено, щуо регулювання природних монополій в Україні здійснюється Національними комісіями, які є центральними органами виконавчої влади із спеціальним статусом, щчо утворюються та ліквідуються Президентом Украӥни. Досліджено деякі особливості функиіонування регуляторних органів сфери телекомунікацій на прикладі країн Свропейської Співдружності та Украӥни.

Зроблено висновок, щчо загальна кількість органів влади, яким повинен звітувати орган регулювання у сфері телекомунікацій, а також орган влади, відповідальний за ухвалення бюджету, різниться за крайнами ЄС. Однак основним джерелом фінансування органів регулювання сфери телекомунікацій у більшості країн СС є надходження за результатами власної діяльності.

Особливу увагу в роботі було приділено дослідженню функиій органів регулювання у сфері телекомунікацій. Зроблено висновок, щзо важливою складовою діяльності органів регулювання є забезпечення надання універсальних послуг як важливої соціальної складової ринку.

Ключові слова: публічне управління, державне управління, державне регулювання, національна комісія, регуляторні органи, сфера телекомунікацій.

Табл.:1. Рис.: 3. Літ.: 25.

\section{ГОСУДАРСТВЕННОЕ РЕГУЛИРОВАНИЕ В СФЕРЕ ТЕЛЕКОММУНИКАЦИЙ: КОНЦЕПТ И МЕХАНИЗМЫ}

ВОРОНЕНКО Ирина Викторовна, Кандидат экономических наук, стариий научный сотрудник, докторант кафедры экономической кибернетики, Национальный университет биресурсов и природопользования Украины (2. Киев)

В статье рассмотрены и обобщены научные подходы к определению сущности государственного регулирования. Установлено, что наряду с понятием государственного регулирования, широкое применение приобрели понятия "публичное управление" и "государственное управление". Путём сравнительного анализа раскрыто содержание данных понятий $u$ их взаимосвязь. $B$ ходе исследования установлено отсутствие единого понимания и общепринятой трактовки понятия государственного регулирования.

Отмечено, что регулирование естественных монополий в Украине осуществляется Национальным комиссиями, которые являются центральными органами исполнительной власти со специальным статусом, создаются и ликвидируются Президентом Украины. Исследованы некоторые особенности функиионирования регуляторных органов сферы телекоммуникачий на примере стран Европейского Союза и Украинь. 


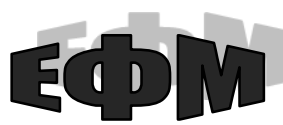

http://efm.vsau.org/

Сделан вывод, что общее количество органов власти, которым должен отчитываться орган регулирования в сфере телекоммуникачий, а также орган власти, ответственный за принятие бюджета органа регулирования разнится по странам ЕС. Однако основным источником финансирования органов регулирования сферы телекоммуникаций в большинстве стран ЕС являются поступления по результатам собственной деятельности.

Особое внимание в работе было уделено исследованию функиий органов регулирования в сфере телекоммунакаций. Сделан вывод, что важной составляющей деятельности органов регулирования является обеспечение предоставления универсальных услуг как важной социальной составляющей рынка.

Ключевые слова: публичное управление, государственное управление, государственное регулирование, национальная комиссия, регуляторные органы, сфера телекоммуникаций.

Табл.: 1. Рис.: 3. Лит.: 25.

Formulation of the problem. Formation of an effective mechanism of state regulation is a multifaceted dynamic problem, whose components tried to consider the thinkers of ancient Rome, Greece, India, China, Egypt, and Shumer in their scientific works. Scientists make assumptions about the inevitability of the presence of signs of state regulation, respectively, and problems and attempts to solve them, since the advent of statehood in general, in particular the founding of the first organized societies [1].

However, to date, despite the millennial history of the study of this problem, native and foreign scientists haven't been able to agree on establishing a unified approach to the definition of the concept of "state regulation", to propose an effective mechanism and criteria for the effectiveness of its functioning, and moreover, even agree on its overall appropriateness.

Analysis of recent research and publications. The questions of the essence of state regulation researched in their writings such scientists as V. Karsekin [2], E. Kubko [3], I. Mikhasyuk [4], S. Stepanenko [5], D. Stecchenko [6], and others. The lack of a single scientific thought about this problem emphasizes not only the fact of pluralism in determining the essence of the notion of "state regulation," but also the availability of other terms which define the relationship of relations between the state and society, their characteristics, such as: "state intervention," "public administration", "governance", "state regulation" and lack of a common view on the differences between them.

Thus, there is a need in the research of the evolution of the definition of the essence of state regulation on the basis of the method of analysis and synthesis of scientific works of leading scientists in this regard, main provisions regarding the key principles of the state regulatory policy of Ukraine and some features of functioning of the regulatory authorities of the sphere of telecommunications.

Formulation of the aim of the research. The purpose of the article is to study evolution of the definition of the essence of state regulation, main provisions regarding the key principles of the state regulatory policy of Ukraine and basic concept and mechanisms of state regulation in the field of telecommunications.

Presentation of the main research material. To determine the essence of state regulation, first of all it is necessary to clarify the meaning of the terms "regulation" and "management".

In the dictionary of the Ukrainian language, the term "regulate" is defined as "to organize something, to manage something, subordinating it to the corresponding rules, a certain system" [7], and "to manage" - "direct the activity, work of someone, something; be at the head of someone, something; operate"[8]. 
The term "state regulation" is an integral part of the management, which ensures the fulfillment of the function of the state administration, which is why, in our opinion, the concept of "public administration" should be considered.

In Table 1, we present the approaches of different researchers to the content of the concept of public administration, governance and state regulation.

Table 1

\section{Approaches to the content of the concept of public administration and state regulation}

\begin{tabular}{|c|c|}
\hline Researcher & The content of the concept \\
\hline \multicolumn{2}{|r|}{ "public administration" } \\
\hline D. Keeling [10] & $\begin{array}{l}\text { searching for the best way to use resources to achieve the priority goals of } \\
\text { government policy }\end{array}$ \\
\hline S. Chernov [11] & $\begin{array}{l}\text { organizing and regulating the state's influence on the social life of people } \\
\text { in order to organize, preserve or transform it, based on the power that } \\
\text { restricts effective public control }\end{array}$ \\
\hline \multicolumn{2}{|r|}{ "governance" } \\
\hline G. Atamanchuk [12] & $\begin{array}{l}\text { practical, organizing the influence of the state on the social life of people } \\
\text { in order to regulate, preserve or transform, based on its power }\end{array}$ \\
\hline V. Averyanov [13] & $\begin{array}{l}\text { the activity of the state, based on its management, that is, organizational } \\
\text { influence on those spheres and sectors of public life that require a certain } \\
\text { state interference through the use of powers of the executive }\end{array}$ \\
\hline $\begin{array}{l}\text { V. Bakumenko } \\
\text { P. Nadolishniy [14] }\end{array}$ & $\begin{array}{l}\text { activity on the implementation of state powers in order to fulfill its } \\
\text { organizational and regulatory and service functions in society in general } \\
\text { and in certain spheres of his life }\end{array}$ \\
\hline S. Lobozinskaya [15] & $\begin{array}{l}\text { administrative action, the implementation of which is carried out by the } \\
\text { mechanisms of planning, organization, motivation, regulation and control }\end{array}$ \\
\hline \multicolumn{2}{|r|}{ "state regulation" } \\
\hline A. Azrilian [17] & $\begin{array}{l}\text { the influence of the state on the activities of economic entities and market } \\
\text { conditions in order to ensure normal conditions for the functioning of the } \\
\text { market mechanism, the resolution of environmental and social problems }\end{array}$ \\
\hline A. Ignatyuk [18] & $\begin{array}{l}\text { a set of methods and tools aimed at increasing production volumes, improving the } \\
\text { structure of sectoral markets, developing and implementing scientific and } \\
\text { technological advances, strengthening the competitiveness of the economy, } \\
\text { increasing export potential and effectively addressing social problems }\end{array}$ \\
\hline V. Karsekin [2] & $\begin{array}{l}\text { a set of forms, methods, means of influencing the economy, covering the } \\
\text { economic relations that have developed between subjects and objects of } \\
\text { regulation in the process of definition and realization of the purpose }\end{array}$ \\
\hline E. Kubko [3] & $\begin{array}{l}\text { conditions for the activities of entities and objects in the direction that is } \\
\text { desirable for the state and which will be the development of the } \\
\text { management system as a whole }\end{array}$ \\
\hline C. Mocherny [19] & $\begin{array}{l}\text { a complex of main forms and methods of purposeful influence of state } \\
\text { institutions and organizations on the development of the social mode of } \\
\text { production for its stabilization and adaptation to changing conditions }\end{array}$ \\
\hline S. Stepanenko [5] & $\begin{array}{l}\text { purposeful activity of the state in creating the legal, economic and social } \\
\text { prerequisites necessary for the most effective functioning of the market } \\
\text { mechanism and minimization of its negative consequences }\end{array}$ \\
\hline D. Stechenko [6] & $\begin{array}{l}\text { the state's influence on reproduction processes in the economy by means } \\
\text { of appropriate means for orientation of economic entities and individuals } \\
\text { to achieve the goals and priorities of public policy of social development }\end{array}$ \\
\hline
\end{tabular}




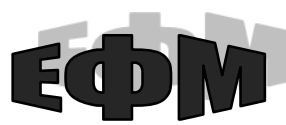

http://efm.vsau.org/

Understanding the presence of a certain pluralism in defining the content of the concept of public administration and state regulation, I agree with Finkilstein O.V., who in his work notes "The main difference between government and state regulation is the way of organizing relations between the state and other actors, and in the basis of the choice of regulation or management lies in the specifics of the sphere and the goals of the state that are being realized". We emphasize that "state-of-the-nation", which obviously depends on many internal and external factors, differ at a specific time, including for different markets.

As for Ukraine, according to the provisions of the Law of Ukraine "On the Principles of State Regulatory Policy in the Field of Economic Activity", the regulatory authority is the Verkhovna Rada of Ukraine, the President of Ukraine, the Cabinet of Ministers of Ukraine, the National Bank of Ukraine, the National Council of Television and Radio Broadcasting of Ukraine, another government body, the central executive authority, the Verkhovna Rada of the Autonomous Republic of Crimea, the Council of Ministers of the Autonomous Republic of Crimea, the local executive authority, the local self-government body, as well as the post the advertent person of any of these bodies, if, in accordance with the law, this person has the power to take regulations alone. Regulatory authorities also include territorial bodies of central executive bodies, state specialized institutions and organizations, non-profit self-governing organizations that manage and manage certain types of compulsory state social insurance, if these bodies, institutions and organizations in accordance with their authority adopt regulatory acts [19]. This document also defines the definition of regulatory activity, which refers to activities aimed at the preparation, adoption, monitoring of the effectiveness and review of regulatory acts, which are carried out by regulators, natural and legal persons, their associations, territorial communities within, in the order and in the manner established by the Constitution of Ukraine, this Law and other normative-legal acts.

The legal, economic and organizational principles of the state regulation of activities of natural monopoly entities in Ukraine, which are carried out with the purpose of ensuring the effective functioning of markets that are in a state of natural monopoly, on the basis of balancing the interests of society, subjects of natural monopolies and consumers of their goods, occupy a special position in this system [20]. According to the Law of Ukraine "On Natural Monopolies", the activities of natural monopoly entities are regulated in the following areas: transportation of oil and oil products by pipelines; transportation of natural and oil gas by pipelines and its distribution; transportation of other substances by pipeline transport; transmission and distribution of electric energy; use of railways, dispatching services, railway stations and other objects of infrastructure providing traffic of generalpurpose railway transport; air traffic control; general communication; centralized water supply and drainage; centralized supply of heat energy; specialized services of transport terminals, ports, airports on the list, which is determined by the Cabinet of Ministers of Ukraine, as well as adjacent markets.

It should be noted that the regulation of natural monopolies is carried out by the National Commissions, which are central bodies of executive power with a special status, which are formed and liquidated by the President of Ukraine. These National Commissions include: National Commission for state regulation in the area of communication and information, the National Commission for state regulation in the energy and utilities areas, the National Commission for securities and stock market, the National Commission that performs state regulation in the field of financial services markets, the National Commission, which carries out state regulation in the field of financial services markets. 
In turn, each of these National Commissions is guided by a separate set of normative legal documents in which, among other, the purpose of state regulation in this area and the tasks and powers of the regulatory body are defined, the requirements for the procedure for state supervision, the composition and procedure for the appointment of members of the National Commission are formulated, financing, scientific and methodological and informational support of the activities of the National Commission.

Taking into account that at present for most countries the development of the information society is one of the national priorities, and information and communication technologies are a necessary tool of socio-economic progress, one of the main factors of innovation development of the economy, we examined some features of functioning regulatory authorities of the sphere of telecommunications on an example of the European Union and Ukraine [21].

Thus, the total number of authorities that has to be reported by the telecommunications regulatory authority varies according to EU countries, in 13 countries the regulatory body is accountable to 1 body, in 6 countries to 2, in 3 countries to 5 , in 4 countries to 3 , in 5 countries to 1 . Among them in 15 countries the regulatory body is accountable to the legislature of the country, 11 to the Sector Ministry, 6 to the public, and 5 to the Government (Fig. 1).

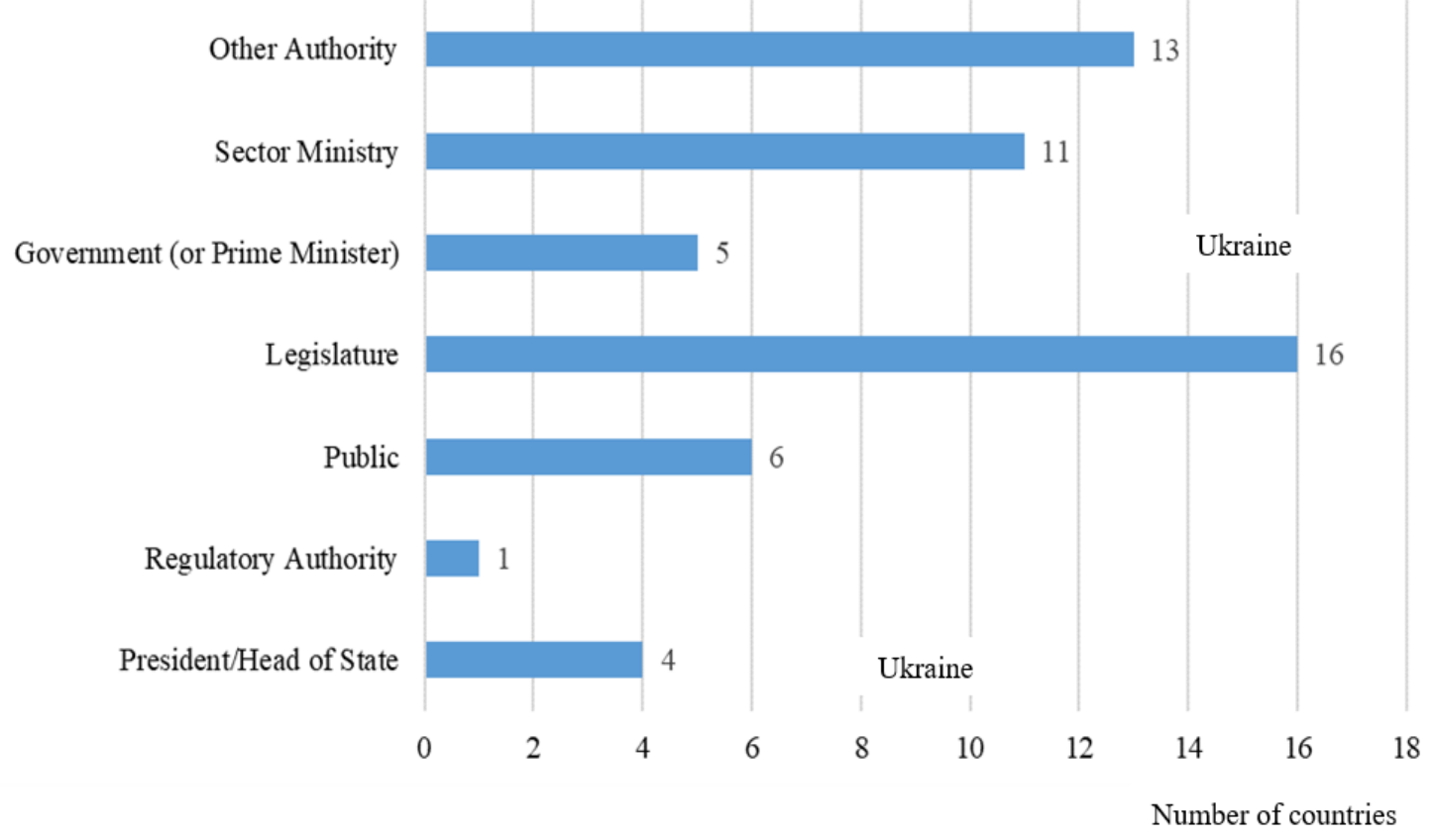

Fig. 1. Name of the authority which has to be notified by the regulatory authority in the field of telecommunications (according to EU countries and Ukraine)

Regarding the budget of telecommunications recall bodies, it is regulated by the regulator itself in $12 \mathrm{EU}$ countries, in $12 \mathrm{EU}$ countries the government of those countries do the same at one time, in 3 countries it is done by the legislative authority and 3 countries it is done by the sectoral Ministry. The main source of financing for regulators in $18 \mathrm{EU}$ countries is income from their own activities. In total, among 28 EU countries 12 countries use the state budget to finance the regulatory authority, but only in 7 countries the proceeds from the state budget are more than 50 percent of the budget of the regulatory authority. 


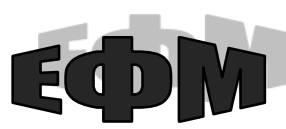

http://efm.vsau.org/

Fig. 2 for the sake of clarity is the data on the distribution of powers of state authorities in the field of telecommunications. Therefore, the main functions of regulators in this area are quality of service standards setting, interconnection rates, enforcement of quality of service obligations, spectrum Monitoring and Enforcement, charge of numbering, price regulation, licensing, universal service/access, enforcement of quality of service obligations, broadcasting (sound transmission) and radio frequency allocation and assignment.

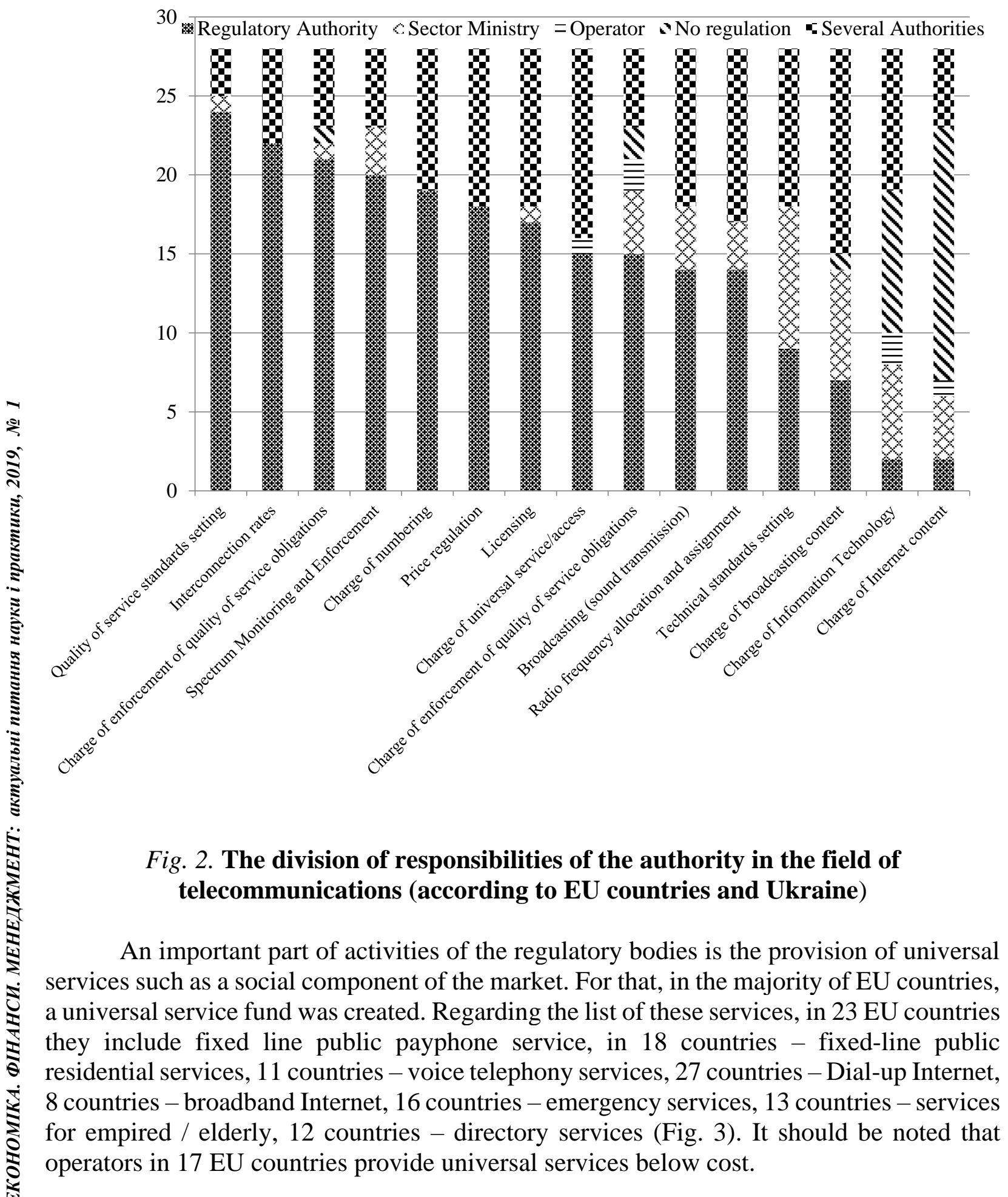




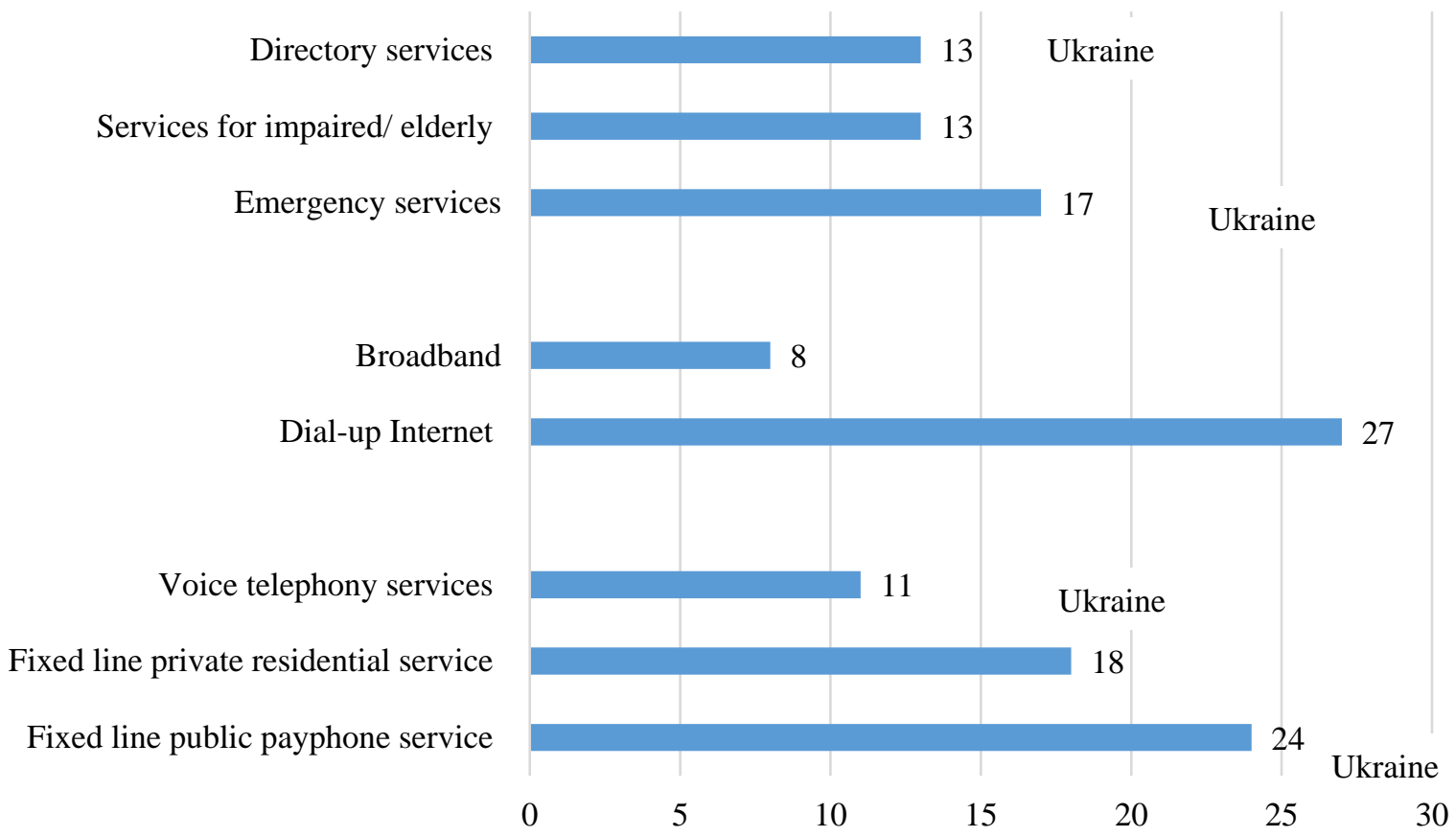

Fig. 3. List of universal services in the field of telecommunications (according to EU countries and Ukraine)

Obviously, the lack of access to the Internet in the list of universal in Ukraine contradicts the general tendencies.

By systematizing the results of the comparative analysis of normative legal acts of Ukraine on this issue, we note that for the first time we meet the terminology in 1992, namely the Law of Ukraine "On Information" of October 2, 1992, No. 2657-12 [22], which regulates the conceptual concepts important for forming the essence of the telecommunications, such as: "information protection", "information relations and their subjects," etc.

During the regular meeting on February 4, 1998, the Verkhovna Rada of Ukraine adopted the Law of Ukraine "On the Concept of the National Program of Informatization" No. 75-98 [23]. This document discloses the essence of the term "informatization", which refers to a set of interrelated organizational, legal, political, socio-economic, scientific and technical, production processes, aimed at creating conditions for meeting information needs, the realization of the rights of citizens and society on based on the creation, development, use of information systems, networks, resources and information technologies, created on the basis of the use of modern computing and communication technology. In addition, the document regulates a number of facts that determine the poor state and explain the slowly development of the informatization process on the territory of Ukraine, among which: the lack of connection to the Internet, lack of funding, inconsistency in the use of information resources, lack of a systematic approach, the use of outdated technical equipment, etc. It is worth noting that the following terms are used in the text of the document: "information resource", "information security", "information infrastructure", "information services".

On June 19, 2003, the Verkhovna Rada of Ukraine adopted the Law of Ukraine "On the Fundamentals of National Security of Ukraine" No. 964-IV, which identified the main real and potential threats to the national security of Ukraine and the stability of society in 
various spheres. The threats to the national security of Ukraine in the information sphere include: manifestations of restrictions on freedom of speech and access to public information; media dissemination of the cult of violence, cruelty, pornography; computer crime and computer terrorism; disclosure of information constituting a state secret or other information with restricted access aimed at meeting the needs and ensuring the protection of the national interests of society and the state; attempts to manipulate social senses, in particular, by disseminating inaccurate, incomplete or biased information.

On September 16, 2014, the Verkhovna Rada of Ukraine adopted the Law of Ukraine "On Ratification of the Association Agreement between Ukraine, on the one hand, and the European Union, the European Atomic Energy Community and their Member States, on the other hand" No. 1678-18 [24]. Adoption of this agreement implies full and unconditional cooperation between Ukraine (on the one hand) and EU member states (on the other hand) in combating criminal activity and crime, including cybercrime. As a result of the agreement, in the objectives of the National Security Strategy of Ukraine, threats to cybersecurity and information security began to appear among the actual threats. However, these notions at the time of the adoption of the Law were not regulated by the normative legal acts of Ukraine. Among the cyber threats in the Law, the vulnerability of information resources and critical infrastructure resources to cyber attacks is noted. Providing state security in the areas of information and cyber security, together with cyber intelligence, has officially become the authority of the intelligence, counterintelligence and law enforcement agencies. Among the priorities of cyber security and safety of information resources, this Law defines the following: the development of information infrastructure, the creation of a system of cyber security (CERT), the continuous monitoring of cyberspace for possible cyber attacks, and the development of agencies for the investigation of cybercrime. Later, on November 30, 2015, the Ministry of Foreign Affairs, by its letter No. 72 / 14-612 / 12980 dated November 30, 2015, will officially count the "provisional application" of the Agreement on January 1, 2016.

The main positions mentioned above appear in the Decision of the National Security Council of Ukraine "On the Strategy of National Security of Ukraine" dated May 6, 2015 and put into force on May 26 of the same year by the Presidential Decree of Ukraine.

The Law of Ukraine "On the Basic Principles of Cybersecurity of Ukraine" [25] already clearly regulates the concept of cyberspace and, on its basis, formalises a large number of provisions. According to this Law, cyberspace is an environment (virtual space) that provides opportunities for communications and/or the realization of social relations, formed as a result of the operation of compatible (connected) communication systems and the provision of electronic communications using the Internet and/or other global data transmission networks.

Thus, since 1991 there have been significant changes in the field of telecommunications of Ukraine, which has a significant impact on all spheres of public life of the country, national security, development of the national economy, ensuring its level of competitiveness, improving the living conditions of people.

In this regard, the priority direction of state policy is to develop approaches and principles of the field of telecommunications development depends on the effectiveness of state regulation in this area. 
A thorough analysis of the powers of the state authorities in the field of regulating the field of telecommunications of Ukraine, namely 18 Ministries, 4 National Committees, 19 Services, 10 Agencies, 10 Inspections, 3 other central executive bodies, and 7 central executive bodies with special status, allowed to distinguish the main bodies government in this area:

1. The National Commission, which carries out state regulation in the field of communication and information, ensures the implementation of a unified state policy on state regulation, carries out supervision, realizes the state strategy of development in the field of telecommunications, informatization and development of the information society, the use of HRD, the provision of postal services; provides systematic, comprehensive and coherent development of informatization and information society in the state; carries out management and coordination of activities on the issues of the formation and use of state electronic information resources, ensures the maintenance of the National Register of electronic information resources of state authorities.

2. The State Service for Special Communications and Information Protection of Ukraine ensures the formation and implementation of state policy in the spheres of cryptographic and technical protection of information, telecommunications, use of the radio frequency resource of Ukraine, special-purpose postal mail, the government's telegraphic communication, protection of state information resources and information in information, telecommunication and information-telecommunication systems and on the objects of information activity, as well as in the areas of use information resources in terms of information security, countering technical intelligence, performance, security and development of the state system of governmental communications, national system of confidential communications; participates in the formation and implementation of state policy in the field of electronic document circulation in the field of information protection of state bodies and local self-government bodies, development and introduction of electronic digital signature in state and local self-government bodies.

3. The State Agency for E-Governance of Ukraine implements the state policy in the field of informatization, e-governance, the formation and use of national electronic information resources, the development of the information society; organizes conducting of forecast-analytical studies on the state of development of the information society, egovernment and the sphere of informatization; provides methodological, regulatory, informational and organizational support to the processes of formation and implementation of the National Informatization Program; carries out state registration of electronic information resources of state bodies, bodies of local self-government and other legal entities of public law, access to which is carried out through public telecommunication networks, and issues corresponding certificates; coordinates the activities of executive authorities related to the creation and integration of electronic information systems and resources in the Single Web portal of executive bodies and the provision of information and other services through the electronic information system "Electronic Government"; approves the methodology for the formation of indicators for the development of the information society; develops proposals on the definition of the goals and objectives of the state information policy, ways of its implementation; provision of general coordination of activities of state bodies on the development of the information society; establishment of standards, norms, rules, orders, classifiers in the field of informatization, e-governance and information society development; Determining the order of information content and technical support of the Single web-portal of executive bodies; the order of functioning of 


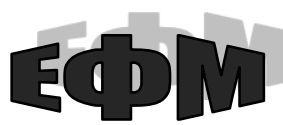

http://efm.vsau.org/

official websites of executive bodies; Participates in the definition of priority directions of informatization and provision of information security of the state; informs the public on the state of the development of the information society and promotes the benefits of its construction.

Conclusions. In the article it is reviewed and generalized scientific approaches to the definition of the essence of state regulation, and systematized the evolution of the views of scientists on the role of the state in regulation. It has been shown that "governance", "public administration", "state regulation" should not be used as synonyms to each other. Understanding the strain and complexity of the state regulation system, the main provisions concerning the key principles of the state regulatory policy of Ukraine are presented.

Telecommunications, as a natural monopoly, are subject to mandatory regulation in accordance with world experience, unlike other spheres of the economy, whose activities can only be provided by an executive body. A significant part of the regulatory authorities of the EU countries are independent, financed by the results of their own activities, as opposed to the regulatory body of Ukraine financed by the state budget.

An important part of activities of the regulatory bodies is the provision of universal services as a social component of the market. Regarding the list of these services, in $23 \mathrm{EU}$ countries they include fixed line public payphone service, in 18 countries - fixed-line public residential services, 11 countries - voice telephony services, 27 countries-Dial-up Internet, 8 countries - broadband Internet, 16 countries - emergency services, 13 countries - services for empired / elderly, 12 countries - directory services. Therefore, in our opinion, it is necessary to include provision of services of access to the Internet in Ukraine to the list of universal ones. The subject of further research interests will be studying the peculiarities of regulation of telecommunications and information technology in Ukraine.

There are presented the results of the analysis of the authorities regarding the regulation in the field of telecommunications of Ukraine, which will reveal the shortcomings of the legal and regulatory framework for the regulation in the field of telecommunications in Ukraine and develop proposals for its improvement, which in turn will contribute to the emergence of a qualitatively new level of socio-economic security in general, and, in particular, the cybersecurity of Ukraine in conditions of increased external and internal threats.

As a whole, the results of this study revealed problematic issues that will allow to assess in the future the compliance of the legal and regulatory framework for the regulation in the field of telecommunications of Ukraine in accordance with the requirements of international law, and also become the cornerstone for forming recommendations on the elimination of key issues of the interaction mechanism taking into account direct and reverse links Information and flow of information for the following players of the Ukrainian market: "International organizations" - "Government bodies in Ukraine" - "Business entities" - "Consumer of services".

\section{References}

1. Novikova, N.L. (2016). Derzhavne reghuljuvannja ekonomichnykh interesiv aghrarnoji sfery [State regulation of the economic interests of the agrarian sector]. Doctor's thesis. Kyjv: Nac. nauk. centr "In-t aghrar. ekonomiky" [in Ukrainian].

2. Karsekin, V.I. (2009). Udoskonalennja instrumentiv finansovo-investycijnoji polityky u sferi derzhavnogho reghuljuvannja [Favorable investment policy investment policy in the sphere of state regulation]. Kyjv: Znannja [in Ukrainian]. 


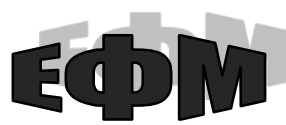

http://efm.vsau.org/

3. Kubko, E.V. (1988). Program-target organization of public administration (Essence, legal basis, economic practice) [Program-target organization of public administration (Essence, legal basis, economic practice)]. Kyjv: Naukova dumka, [in Russian].

4. Mykhasjuk, I. (2000). State regulation of the economy: a textbook [State regulation of the economy: a textbook]. Kyjv; Atika, Eljgha-N [in Ukrainian].

5. Stepanenko, S. V. (2013). Osnovni pidkhody, naprjamy ta instrumentariji derzhavnogho reghuljuvannja ekonomiky [The main approaches, directions and tools of state regulation of the economy]. Retrieved from: http://www.kbuapa.kharkov.ua/ebook/db/2013-2/doc/2/03.pdf [in Ukrainian].

6. Stechenko, D. M. (2000). Derzhavne reghuljuvannja ekonomiky: navch. posib [State regulation of the economy: teaching. manual]. Kyjv, MAUP [in Ukrainian].

7. Bilodid, I. K. (1997). Slovnyk ukrajinsjkoji movy: $v 10 \mathrm{t}$. [Dictionary of the Ukrainian language: 10 t]. Kyjv: Nauk. dumka. Retrieved from: http://ukrlit.org/slovnyk/slovnyk_ukrainskoi_movy_v_11_tomakh/\%D1\%83\%D0\%BF\% D1\%80\%D0\%B0\%D0\%B2\%D0\%BB\%D1\%8F\%D1\%82\%D0\%B8 [in Ukrainian].

8. Bilodid, I. K. (1997). Slovnyk ukrajinsjkoji movy: $v 11$ t. [Dictionary of the Ukrainian language: 11 t]. Kyjv: Nauk. dumka. Retrieved from: http://ukrlit.org/slovnyk/slovnyk_ukrainskoi_movy_v_11_tomakh/\%D1\%83\%D0\%BF\% D1\%80\%D0\%B0\%D0\%B2\%D0\%BB\%D1\%8F\%D1\%82\%D0\%B8 [in Ukrainian].

9. Zborovsjka, O. (2009). Teoretychni koncepciji materialjnoji osnovy derzhavnogho reghuljuvannja ekonomiky [Teoretychni koncepciji materialjnoji osnovy derzhavnogho reghuljuvannja ekonomiky]. Ekonomika ta derzhava, 8, 5-7. [in Ukrainian].

10. Keeling, D. (1972). Management in Government. London: Allen \& Unwin [in Russian].

11. Chernov,S. I. (2014). Publichne administruvannja [Public administrat]. Kyjv, Khark. nac. un-t misjk. ghosp-va im. O. M. Beketova [in Ukrainian].

12. Atamanchuk, Gh.V. (2000). Ghosudarstvennoe upravlenye. Uchebnoe posobye [Public administration]. Moskow: Encyklopedija upravlencheskikh znanij [in Russian].

13. Aver'janov, V.B. (1999). Derzhavne upravlinnja v Ukrajini [Public administration in Ukraine]. Kyjv: Instytut derzhavy i prava im. V.M. Korecjkogho [in Ukrainian].

14. Bakumenko, V.D. (2003). Teoretychni ta orghanizacijni zasady derzhavnogho upravlinnja [Theoretical and organizational principles of state administration]. Kyjv: NADU [in Ukrainian].

15. Lobozynsjka, S. M. (2010). Derzhavne reghuljuvannja bankivsjkoji systemy Ukrajiny [State regulation of the banking system of Ukraine]. Ljviv: Ljviv. nac. un-t im. I. Franka [in Ukrainian].

16 Azrylyjan, A. N. (1997). Boljshoj ekonomycheskyj slovarj [The Great Dictionary of Economics]. Moskow [in Russian].

17. Ighnatjuk, A.I. (2009). Metodologhija doslidzhennja funkcionuvannja ghaluzevykh rynkiv [Methodology for researching the functioning of sectoral markets]. Ekonomichna teorija, 3, 60-74 [in Ukrainian].

18. Mochernyj, S. V. (1999). Ekonomichna teorija: posib. dlja studentiv vyshhykh navch. zakl. osvity [Economic theory]. Kyjv: VC "Akademija” [in Ukrainian].

19. Zakon Ukrainy Pro zasady derzhavnoi rehuliatornoi polityky u sferi hospodarskoi diialnosti 11.09.2003 № 1160-IV [Law of Ukrain On the Principles of State Regulatory Policy in the Field of Economic Activity from 11.09.2003 №1160-IV]. Retrieved from: http://zakon2.rada.gov.ua/laws/show/1160-15/print1517244542228105 [in Ukrainian]. 
20. Zakon Ukrainy Pro pryrodni monopolii 20.04.2000 № 1682-III [Law of Ukraine On Natural Monopolies fron 11.09.2003 №1160-IV]. Retrieved from: http://zakon2.rada.gov.ua/laws/show/1160-15/print151724454222810 [in Ukrainian].

21 Focus Areas - Regulatory Information. Retrieved from: https://www.itu.int/net4/itu-d/icteye/FocusAreas.aspx?paramWorkArea=TREG.

22. Zakon Ukrainy Pro informatsiiu 02.10.1992 №2657-XII [Law of Ukraine About information from 02.10.1992 №2657-XII]. Retrieved from: hthttp://zakon2.rada.gov.ua/laws/show/2657-12/ed20170101 [in Ukrainian].

23. Zakon Ukrainy Pro Kontseptsiiu Natsionalnoi prohramy informatyzatsii 11.08.2013 №406-VII [Law of Ukraine About the Concept of the National Program of Informatization from 11.08.2013 № 406-VII]. Retrieved from: http://zakon3.rada.gov.ua/laws/show/75/98-\%D0\%B2\%D1\%80 [in Ukrainian].

24. Zakon Ukrainy Pro ratyfikatsiiu Uhody pro asotsiatsiiu mizh Ukrainoiu, z odniiei storony, ta Yevropeiskym Soiuzom, Yevropeiskym spivtovarystvom z atomnoi enerhii i yikhnimy derzhavamy" 16.09.2014 № 1678-VII [Law of Ukraine On Ratification of the Association Agreement between Ukraine, on the one hand, and the European Union, the European Atomic Energy Community and their Member States, on the other hand from 16.09.2014 №1678-VII]. Retrieved from: http://zakon3.rada.gov.ua/laws/show/1678-18 [in Ukrainian].

25. Zakon Ukrainy Pro osnovni zasady zabezpechennia kiberbezpeky Ukrainy 08.07.2018 № 2469-VIII [Law of Ukraine About the basic principles of providing cyber security of Ukraine from 11.08.2013 №406-VII]. Retrieved from: http://zakon3.rada.gov.ua/laws/show/75/98-\%D0\%B2\%D1\%80 [in Ukrainian].

\section{Інформація про автора}

ВОРОНЕНКО Ірина Вікторівна - кандидат економічних наук, старший науковий співробітник, докторант, Національний університет біоресурсів та природокористування України (03041, Київ, вул. Героїв Оборони, 16А корп. 15, кім. 212, e-mail: irynav@email.ua).

VORONENKO Iryna - Candidate of Economic Siences, Senior Researcher, Doctoral Student, National University of Life and Environmental Sciences of Ukraine (03041, Kyiv, Heroiv Oborony Str. 15 building 3, of. 212, e-mail: irynav@email.ua).

ВОРОНЕНКО Ирина Викторовна - кандидат экономических наук, старший научный сотрудник, докторант, Национальный университет биоресурсов и природопользования Украины (03041, Киев, ул. Героев Обороны, 16А корп. 15, комн. 212, e-mail: irynav@email.ua).

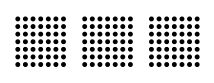

